\title{
Conditions for the development of Vietnamese business and entrepreneurship in Poland
}

\author{
Nguyen Hoang Tien*
}

\begin{abstract}
This paper outlines the history of the development of Vietnamese business and Vietnamese businessmen and entrepreneurs community in Poland. This special period of history of development was to be divided into two main phases. In addition, this article has analyzed the factors affecting international entrepreneurship spirit and international entrepreneurship capacity of this Vietnamese business community here in Poland. These factors are well identified in the overview part of international startups and international entrepreneurship study. The study showed that these factors include: foreign market appeal, government policies, compatibility of business practices, and adaptability to foreign markets. In the research part of this article, these factors were taken to be reanalyzed for the Vietnamese business community in Poland and showed why Vietnamese people choose Poland to be a good place for family settlement and for doing long-term business. Moreover, the success factors and success barriers behind their business development compared to the community of Chinese businessmen and entrepreneurs who came to Poland just only several years later have also been clearly identified. The research results show that, to strengthen the position and to raise the business awareness of Vietnamese business community in Poland, to strengthen it into a more developed and unified community for the purpose of future sustainable development, Vietnamese embassy in Poland with all of its networks of partnership, Vietnam's foreign trade promotion and trade representative agencies, and the diverse Vietnamese associations in Poland, both for profit and non-profit, need to play an interactive role to support Vietnamese businessmen and entrepreneurs to understand indigenous business practices, to overcome language and culture barriers in a bid to better integrate with the Polish business and social environment.

Key words: Vietnam, Poland, Business, Entrepreneurship
\end{abstract}

Thu Dau Mot University, Viet Nam

Correspondence

Nguyen Hoang Tien, Thu Dau Mot University, Viet Nam

Email: vietnameu@gmail.com

History

- Received: 16-12-2018

- Accepted: 20-03-2019

- Published: 31-03-2019

DOI :

https://doi.org/10.32508/stdjelm.v3i1.538

\section{Check for updates}

\section{Copyright}

(c) VNU-HCM Press. This is an openaccess article distributed under the terms of the Creative Commons Attribution 4.0 International license.

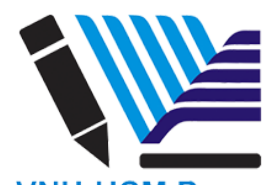

VNU-HCM Press

\section{INTRODUCTION}

Vietnamese community in Poland has been forming since the beginning of 1990s or even earlier. In the very first moment, when communist party was still reigning in Poland, many Vietnamese students, researchers had studied and worked in Poland as Poland was the most favorable country and the most popular destination in the former European socialist block. Together with the time passing, they brought their families to Poland, legalized their longterm stay, forming the core elements of current Vietnamese community small but still growing, in Poland. Since the beginning of the last decade of the previous century Vietnamese people had created their own small businesses which operates mainly in garment, footwear, underwear and several year later, also in gastronomic (food and beverage) sector. Those years were the first stage of transformation of Poland towards the market economy.

In the second decade of history of Vietnamese community in Poland, that was the first decade of XXI century, when Vietnam was to start to develop both economically and socially (marked by the moment of signing Free Trade Agreement with USA in 2001) and Poland became more attractive market for foreign companies as it was the largest and fast changing country in the region, Vietnamese people and people of other nations massively arrived in Poland, mainly for business purposes. That was a second phase of the formation of Vietnamese community. During that time, China was also rising and many Chinese have chosen Poland as a place to live and to conduct their businesses forming Chinese alongside Vietnamese community in Poland.

\section{LITERATURE OVERVIEW}

Barriers to international entrepreneurship are defined as attitudinal, structural, operational, and other that hamper managers' ability to innovate, develop, and retain international business projects or operations ${ }^{1}$. Those barriers have been influencing international businesses at different stages that entrepreneurs should take them under thorough consideration ex- 
ante and ex-post as well in order to eliminate their negative impacts. Many barriers have been identified in the international business literature. In a very diverse extant literature a convergence concerning the most potential barriers for international business and international entrepreneurship includes several following factors in the Table $\mathbf{1}^{2}$ :

1. Foreign market attractiveness;

2. Government policy;

3. Incompatible business practices;

4. Adaptability to foreign market.

Ad 1. Foreign market attractiveness:

- Difficulty in balancing the financial inflow and outflow to retain liquidity - this is a real problem leading many companies to the ironic situations, when their business seems to be profitable but insolvent or when their business seem to suffer heavy losses but the liquidity still high. This is due to serious cash flow problems ${ }^{3}$.

- Difficulty in providing after-sales service - enhancing the after-sales service is treated as a value-added operation which certainly increases the company's popularity and reliability and performance as a consequence;

- Added costs (transport, insurance, market research, distribution) to the original price of products - in case of small and starting companies, those costs, carefully calculated and added all up, may prove the unprofitability of the business, at least in the first stage ${ }^{4}$;

- Exchange rates - the risk of fluctuating foreign exchange rates should be covered by buying insurance $^{5}$, but that will impact economically on business's performance and competitiveness.

Ad 2. Government policy: lack of assistance and support - different kind of institutional assistance is needed in different stage of the business internationalization process ${ }^{6}$. Government supports may be of different characters such as informative, legal, financial (subsidies), promotive, protective, relationship building, tax incentive, etc.

Ad 3. Incompatible business practices: predominant business practices - local business practices are predominant and should be understood both in the dayto-day business behavior and in the cultural background $^{4}$. In order to perceive it well, the business environment should be thoroughly analyzed by and for the managers to be more culturally, politically and socially sensitive.

Ad 4. Adaptability to foreign market: differences in customer preferences, rules and regulations concerning product usage, pricing and promotion strategy in foreign market should be leveled down to tailor to the needs of the customers and requirements of local authorities $^{7,8}$. In order to do it well, the knowledge of the foreign market should be enhanced and strongly popularized.

\section{METHODOLOGY}

The study of Vietnamese community in Poland presented here is designed to use qualitative researching methods to find out and analyze factors impacting international entrepreneurship. Qualitative research is needed when one has to deal with descriptive measures serving to enhance the innovativeness and engagement in international business. Qualitative methods, both formal and informal, enable author to deal with open, flexible and fast changing issues related to a given topic in order to provide in-depth understanding the interviewed respondents and experts in terms of their attitudes, perceptions, believes, feelings, points of view and motivations, as well as the essence of the phenomena being studied ${ }^{9}$. Qualitative methods are also used to the preliminary stage of research, furthermore, if needed, quantitative methods operating on statistical data and numbers may be used as a second stage.

The result of the carried out research here are the findings of secondary data analysis and interviews with Vietnamese businessmen community in Warsaw to point out the factors that impact their development and expansion in Polish and EU market. The reason to choose Vietnamese business community in Warsaw as an object of research is that the author have been living and studying in Poland for a very long time and the author knows exactly very well the reality and development conditions of this Vietnamese business community there. The research took two months (summer 2015) to gather and collate necessary information and data regarding the barriers blocking as well as the strong points pushing forwards the internationalization and sustainability of these enterprises.

In total, 101 firms has been analyzed, most of them are product-based (the larger ones) rather than servicebased (the smaller ones). Most of these firms are created and based in Poland, only several are of Vietnamese origin.

The goods that are produced or imported to Poland by these firms, among others, are: clothes, footwear, underwear, electronic household articles, foodstuffs, 


\begin{tabular}{cll} 
Table 1: Barriers to international business and entrepreneurship \\
\hline 1 & Foreign market attractiveness & a)Balancing the financial inflow and outflow to retain liquidity \\
& b)Providing after-sales service \\
& c)Added costs (transport, insurance, market research, distribution) \\
& d)Exchange rates \\
2 & Government policy & Lack of assistance and support \\
3 & Incompatible business practices & Local business practices are predominant \\
4 & Adaptability to foreign market & Differences in customer preferences, local rules and regulations
\end{tabular}

plastic and wooden products, decorative articles. The services offered by service-based companies, among others, embrace: bar and restaurant, legal services, air tickets and travel, babysitting, logistics and dispatching services, house and office for rent, language teaching.

\section{DATA ANALYSIS AND RESEARCH RESULTS}

Market attractiveness of Poland's economy concerns the issues of financial balancing, after sales service, added costs and exchange rates. The character of those issues is changing together with consecutive stages of Polish market development. Poland is the country in the Eastern socialist block whose communist system collapsed first in 1991, and right after that, economic reforms started towards market economy. At this time, the economy was suffering from the lack of goods and services. It was also a time, when small businesses, including export ones, opened up and were thriving due to the lack of competition in the market. The business of Vietnamese enterprises consisted in importing to Poland (exporting from Vietnam) mainly garment and footwear articles. Those weren't of high quality, but were acceptable in Polish market due to the serious lack of goods and competitors in the sector. Then, the infrastructure supporting export such as cargo service and payment systems did present yet poorly. Those services were at the burgeoning state and did not develop quickly enough to fulfill their mission. That was partly due to the lack of competition and the fact that communist mindset were still to function. Since that, export businesses were under diverse barriers to develop their potential and fully explore the favorable market conditions. In such market situations, the idea of aftersales services is hardly heard of, at least not in the case of traditional consumption goods traded mostly by Vietnamese community. Due to the lack of wellperformed logistic infrastructures (transport, insurance, market research and distribution) and the lack of their competitive market, the costs of those services were relatively or even extremely high whereas their quality was simply inadequate. That was the most important reason that forced small businesses, especially the start-up ones, to be unprofitable, hindering the development of SMEs sector which is critically needed for the development and reorientation of the whole economy. The big problem of these years is the exchange rate of Polish currency in relation to US dollar. Due to the progressing hyper-inflation, the Polish Zloty was sharply and continuously losing in value throughout all the first decade of economic transformation. That impacted exporters most, including Vietnamese enterprises, because Vietnam Dong had suffered less from devaluation in relation with US dollar, so its currency was strengthening against Polish Zloty.

In second decade of economic transformation, that is the period of 2000-2010, the Polish economy was stabilizing as it had accessed to the European Union, and since then it was treated by many exporters as an attractive destination market. This was the time when Vietnamese enterprises have been developing their business activities, expanding their goods and services offer, importing mainly from China, competing with growing Chinese business community in Poland. At this stage of development, the competition in all the sectors of economy was intensifying, so the quality of infrastructure facilities in terms of financial and logistic services had been improved. As Poland became one, the largest, of 10 members joining the EU in 2004, the society and the economy in Europe were integrated as never before, many sectors of Polish business activities had to restructure themselves in order to comply with European standards and norms, rules and regulations. Corporate as well as individual customers became more fastidious as they, as never before, had more options to choose from, with a wide range of services and goods offered not only by Polish but also by other European enterprises, as Polish market became a part of the common European 
economic zone. Due to a fierce competition in the common European market the prices of services and goods in Poland became more reasonable while their quality was markedly improved by accepting obligatorily pan-European norms and standards as a basis to comply for all production and service activities. Supportive for all enterprises was the fact that the exchange rate, due to the rising power of Polish economy, remained stable with a tendency of strengthening of Polish Zloty, more against US dollar, less against Euro. The risk of fluctuating foreign exchange rates was brought down as common European currency came into being in 2002 and the Polish Zloty is pegged to it since the first moment. In this phase of economic development in Poland, for Vietnamese enterprises, many barriers that before badly impacted Polish market attractiveness had been taken off. But, many Vietnamese entrepreneurs considered that business development and success were not easy as a decade ago, due to rising competition from all sides as Polish Economy really had been opened up and welcomed businesses from every corner of the world. Vietnamese entrepreneurs had to compete with the local, Chinese, and to some extent, also Turkish businesses striving to tap to a big and still growing pie of Polish market.

Assessing the third stage of Polish market development, the period of global economic downturn, hereafter we will compare the Polish market conditions to other countries in the region. Compared to Vietnamese business community in the North America and Western Europe, the advantage of Vietnamese business community in Poland and other Central and Eastern Europe consisted in the fact that they started their business in a condition where competition was only at the very specific sprouting phase as country started to move to a market economy. It seemed then that there had been an immense room for each business to develop and prosper. Thanks to the propitious market situation, seen by many entrepreneurs as unique opportunity in history, many people in the Vietnamese community had earned themselves colossal assets during a quite short period of time, moving up their business to the medium and large size enterprises. But it was not the case of Vietnamese business community in the North America and Western Europe since this process took longer time due to a great market competition existing in there. Excluding Russia, Poland is a very distinctive market for Vietnamese businesses comparing to other European countries in the region such as the former East Germany, Czech Republic, Slovakia, Hungary, Bulgaria, Romania, Ukraine, Belarus, etc. This is due to many reasons. Firstly, Poland is the largest market in
Central-Eastern part of Europe that has least suffered from the current economic downturn. Secondly, here in Poland, the Vietnamese business community, large in number and economic size, is still thriving being a solid ground to attract more compatriots to come to and to integrate with, both economically and socially. Thirdly and finally, Poland is the country that is situated and oriented most westwards not only geographically, so it is a place where Western businesses meet Eastern businesses. That concerns also Vietnamese community which lately has been carrying out many business activities to make use of the current economic crisis occurring there.

Government policy becomes more and more vital for enterprises to survive and prosper as the institutional context are increasingly sophisticated as well as requirements putting forwards to deal with complex and fast changing business environment. The role of government policy and strategy is to create different kinds of favorable assistance in different stage of the business internationalization process ${ }^{6}$. Those supports may be various such as informative, legal, financial (subsidies), promotive, protective, relationshipbuilding, tax incentive, etc. Policy and strategy created and adjusted in case of need are to support and boost competitiveness of all segments of the economy, to contribute to the overall competitiveness, regardless whether these are inside or outside of a given country. From that point of view, Vietnam's central government should draft out and implement plans to boost the competitiveness of business communities in each country it established foreign relationships as they are integral parts of the Vietnam economy. In case of Vietnamese business community in Poland the embassy and associated organizations and agencies both governmental and private are responsible and play vital role to support the implementation of those guidelines. Towards those general needs, many centers for supporting and promoting business and investment have arisen, for example the ASEANPL center for business and investment set up in 2004 in Warsaw have been served as a bridge to connect European enterprises with ASEAN enterprises in general and Vietnamese enterprises in special, and in the future it may be a branch of the whole system of business and investment support around the world serving the interests of Vietnamese business community both domestic and abroad. Vietnamese embassy in Poland regularly (each year) or irregularly organizes business promotion meetings, conferences and events for Polish and Vietnamese enterprises to acquire information and knowledge concerning Vietnamese and Polish business environment respectively and to seek out potential business opportunities. 
Local foreign business practices are predominant and should be understood by Vietnamese business community both in the day-to-day business behavior and cultural background $^{4}$. In order to do it well, the local business environment should be analyzed carefully by managers in order to be more sensitive to it and even to be deeply rooted in the existing there current cultural, political and social circumstances. In relation to business culture, there is quite a wide range of differences among European and Asian nations. In Vietnam, and in Asia as general, it seems to be easier to get to know someone and start not only business contact if you are open and friendly. In Poland, and in the Western culture as general, to simply start a business conversation is not easy, you have to be introduced by someone who knows both you and the third person very well, otherwise you will be alone. Another example shows that purchasing of a given products required prepay according to one culture while in other culture payment is carried out usually after transaction. In Western culture the holy simple rule "business of business is business" is permanently reigning, but in the East business is strongly and deeply rooted in cultural and social context. That's why many alliances tied between Eastern and Western companies, unlike those tied within Eastern or within Western ones, tend to fail at the later stage of development. The differences in culture seem to be so deep to put the lives of those alliances forward. Clashes of different business practices may occurred and be learned in companies established together by Vietnamese and Polish entrepreneurs otherwise business of those companies may not go further. In reality, Vietnamese people hardly ever create joint business with Polish entrepreneurs, mostly due to just differences not only in culture but also in interest. So far, some Polish business practices are still hard to understand and perceive by Vietnamese entrepreneurs, even by those coming to Poland in the very first moment. This is the point, due to the widespread of cultural distances it is much more difficult for Vietnamese businesses to integrate with the local community than other European nations. Differences in business practices appear also in legal systems, especially the business or environmental law, which are more sophisticated in case of Poland due to the conformity with pan-European legal systems. European legal systems are designed so logically and consistently in a larger extent, comparing to the ones in developing countries, to protect consumers and investors' rights and interests, and additionally to be more environment-friendly.
Adapting to foreign market needs. There are differences in customer preferences, rules and regulation concerning products' design, usage, styling and packaging requirement, pricing, distribution, promotion and adaptation strategy in foreign market that should be leveled down to tailor to the needs of the customers and requirements of local authorities $5,7,8$. In order to do it well, the knowledge of the foreign market should be enhanced and popularized among companies. Color, taste and appearance sometimes play an important part in determining business success. Black color closely associated with evil and darkness is strongly avoided in Asian culture, while it is a synonym and symbol of luxury in Europe. Ford, a large automobile industry company formerly was determined to produce only car in black color into the Western market. Returning to Vietnamese businesses, in the first moment, the garment products imported to Poland by Vietnamese companies do not suit Poles because of dissimilarities in size and proportion. For example, the Vietnamese size XXXL is equivalent only to the size $M$ for Poles due to the fact that, on average, Poles are higher and weight heavier than Vietnamese. The problem is not simply solved by renaming the size and making clothes larger. On average, Poles have longer hands than Vietnamese. So, if a shirt fits Poles in size, the sleeves remain too short. So, a shirt design has to change totally in order to adapt to the need of the target market. Another example is the difference in electric socket design for electric and electronic articles. Some Asian manufacturers include to their product a multipurpose plug to comply with the European standards. Next, many foodstuffs require an adequate humidity which is much higher in tropical climate such as Vietnam. Certain food products sold in Vietnamese market do not need airtight packaging, but it is not the case while sold in European markets. Mentioning the case of rice export, one should remember that it is not a very popular dish for many European and Polish families. In Vietnam rice may be sold in $10 \mathrm{~kg}$ packages, while in Polish market packages should be smaller, normally $1 \mathrm{~kg}$ or 400 $\mathrm{g}$ to tailor to the consumption need of common target families. In bar and restaurant business, the flavor of Asian foods and drinks should be changed do adapt to the refined palate of Polish and European people. Chinese foods are greasy, Thai foods are hot, while Vietnamese foods are somewhere between. All that foodstuffs should be deliberately adapted to be successful in the target markets. Last but not least example is related with the distribution system. E-commerce is not popular in Vietnamese culture, at least at present, 
while it is increasingly important distribution channel in Europe. Here in Europe, some products, due to their specification, are sold nearly only online. It is troublesome for Vietnamese exporters to try to find traditional ways to sell their products.

\section{DISCUSSION}

In this paragraph, as a presentation of qualitative analysis, the main topics pointed out in the above literature review, which are market attractiveness, government policy, foreign practices, and adaptation to the market's needs, are subjects of analysis and the results are presented above. The first impacting factor (market attractiveness) and the last impacting factor (adaptation to the market's needs) need further discussion as they are related to the local target market and practices of doing business in Poland by Vietnamese community to adapt and tap to its most potential and profitable segments.

Relating to the first impacting factor, Polish market, as has been described above, has been changing intensively together with passing time. So Vietnamese community's business strategy also should have been adapted to accommodate to changeable market conditions in a bid to profit more from existing market opportunities. In the first order, changes are related to the general attitude, mind-set, and business perception schemes in order to stimulate and kick off innovation processes to generate and implement new business ideas based on the so far developed and fostered cultural and social assets of the community. Next, as a result, changes concern existing models and patterns of doing business that are desperately needed to be restructured in order to fit in today's character of Polish market, in which, on the contrary to the past, several following factors really count:

- Product quality - quality of products or services should be put in the first place as consumers become more and more choosy;

- Product range - products and services should be diversified to meet diverse and changeable needs and preferences of customers;

- Price - price should be reasonable down to the pocket of ordinary customers;

- Distribution - distribution system should be effective and as close as possible to the customers;

- Promotion - discount should be offered as frequent and intensive as possible to lure new customers and attract them from competitors;
- Service - services are indispensable part of sold products or services, more broadly, they create added valued in the eye of customers to retain their loyalty and fidelity;

- Market knowledge - market knowledge concerning customers' preferences, needs, expectations, market conditions, trends and forecasts is very important and has been seen by entrepreneurs as a comparative advantage in a knowledge-based economy.

While it comes to the last impacting factor, different country has a different set of regulations and laws, different requirements concerning, for example, quality or environmental issues, different processes and procedures imposed on businesses or serving to deal with certain business cases. For example, products sold in Polish market required to be marked with detailed information in Polish language concerning the usage mode, ingredients and those informative contents may differ from country to country. Some products require after-sales services in Polish market while they are obligatorily not required in Vietnam or China. The most important in European markets for foodstuffs are safety and hygienic standards carefully watched by governmental sanitary organs and agencies while alimentary safety standards remain simply inadequate, endangering the health of people in developing countries. The tax and duties imposed on imported products in European are subjects of constant change depended on foreign economic policy of the whole European Union as a result of fragile world economic and political situation. This area should be seriously taken into account by many businesses before making trade and investment decisions.

\section{CONCLUSION}

Despite the growing economy at 5\% pace, Vietnamese firms still opt to make their businesses going international because they cannot depend entirely on domestic market in order to catch up the growing pace of foreign companies. Broadly, going international is one of the general trends in business of both developed and developing economies while the world economy is being strongly globalized. This trend may not befall without the assistance of government and its persistent and determined policy and strategy to support and motivate a majority of domestic companies to take part in globalizing and opening up the Vietnam economy. Government, along with its representative agencies, offices all over the world, plays active and guidance roles in promoting and assisting 
in terms of financing, training, information, knowledge and experience sharing, technology transferring, tax concession, legal aspect, etc.

In this present article several points has been discussed in details concerning the current market situation and strategies proposed for Vietnamese enterprises, especially those resided in Poland to tap more effectively to the local foreign market. The contents of points (topics) discussed above, namely the foreign market attractiveness, the government policy, the practices in foreign market, the adaptation to the foreign market needs, do not stand apart and are not subjects of separate analysis. Oppositely, they should be integral parts of an overall analysis to find out integrative strategies and action plans entailed to penetrate foreign markets both by Vietnamese domestic companies and Vietnamese local companies residing and providing operational activities there.

The presented study leads to some interesting findings that significantly contribute to the body of business and management knowledge; several limitations should be noted to be eliminated in the future research:

- Lack of data analysis from Vietnamese firms oversea in other Central-Eastern of Europe in order to compare how market situation differs in details from one country to another in the region and, as a result, to see how a strategy should be adapted to tailor to the nuances of a given country;

- Lack of data analysis from Vietnamese firms oversea in the developed part of the world (West Europe and North America) in order to compare the differences between market conditions and strategies chosen by Vietnamese firms oversea in both part of the world to see the their internationalization process and international entrepreneurship in a big picture.

- Lack of detailed data analysis from Vietnamese firms at home in order to see the differences between strategies chosen by Vietnamese firms oversea and their domestic counterparts to compare the internationalization process and international entrepreneurship of the whole global Vietnamese business community.

In general, the results of this study are confined to entrepreneurship and globalization of Vietnamese firms in certain specific point of time and certain specific place in the world. The results should be tracked over time to point out a sequence of changes in the market conditions and strategies adapted to them. In addition, aside from Vietnamese and Chinese, firms from other developing nations should be subjects of further analysis.

\section{COMPETING INTEREST}

The author declares he has no conflicts of interest.

\section{AUTHOR'S CONTRIBUTION}

Nguyen Hoang Tien has done all the research work of the article as a sole author.

\section{REFERENCES}

1. Leonidou L. Empirical research on export barriers. Journal of International Marketing. 1995;3:29-43.

2. Julian CC, Ahmed ZU. The impact of barriers to export on marketing performance. Journal of Global Marketing. 2005;19:7194.

3. Silva PD, Rocha AD. Perception of export barriers to Mercosur by Brazilian firms. International Marketing Review. 2000;18:589-610.

4. Chung HFL. International Standardization strategies: the experiences of Australian and New Zealand firms operating in the greater China markets. Journal of International Marketing. 2003:11:48-82.

5. Cavusgil ST. Preparing for export marketing. International Trade Forum. 1993;2:16-21.

6. Kotabe M, Czinkota M. State government promotion of manufacturing exports: a gap analysis. Journal of International Business Studies. 1992;23:637-658.

7. Cateora P, Graham J. International Marketing. New York: Irwin/McGraw-Hill; 1996. .

8. Stottinger B. Strategic export pricing: a long and winding road. Journal of International Marketing. 2001;9:40-63.

9. Gordon W, Langmaid R. Qualitative Market Research: A Practitioner's and Buyer's Guide: Gower; 1988. 


\title{
Điều kiện cho sự phát triển kinh doanh và tinh thần khởi nghiệp của cộng đồng người Việt tại $B a L$ an
}

\author{
Nguyễn Hoàng Tiến*
}

Truờng Đại học Thủ Dẩu Một

Liên hệ

Nguyễn Hoàng Tiến, Trường Đại học Thủ Dầu Một

Email: vietnameu@gmail.com

Lịch sử

- Ngày nhận: 16-12-2018

- Ngày chấp nhận: 20-03-2019

- Ngày đăng: 31-03-2019

DOI :

https://doi.org/10.32508/stdjelm.v3i1.538

Check for updates

\section{Bản quyền}

๑ ĐHQG Tp.HCM. Đây là bài báo công bố mở được phát hành theo các điều khoản của the Creative Commons Attribution 4.0

International license.

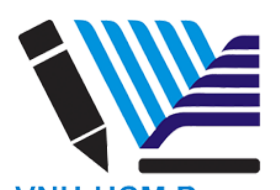

VNU-HCM Press

\section{TÓM TẮT}

Bài viết này trình bày sơ lược lịch sử phát triển cộng đồng doanh nhân và doanh nghiệp Việt Nam ở Ba Lan được phân chia thành hai giai đoạn chính. Ngoài ra, bài viết này đã phân tích các yếu tố tác động đến tinh thần và năng lực khởi nghiệp quốc tế của cộng đồng người Việt này. Các yếu tố này được nhận diện trong phần phân tích tổng quan tài liệu tham khảo quốc tế về khởi nghiệp bao gồm: sức hấp dẫn của thị trường nước ngoài, các chính sách của chính phủ, tính tương thích của các thông lệ tập quán kinh doanh, khả năng thích ứng với thị trường nước ngoài. Các yếu tố này được phân tích lại đối với công đông doanh nhân người Việt tại Ba Lan và đã cho thấy lý do tại sao người Việt Nam lại chọn Ba Lan làm nơi đất lành chim đậu để cư trú, lập nghiệp và kinh doanh lâu dài. Hơn thế nữa, các yếu tố thành công và rào cản phát triển sự nghiệp kinh doanh của họ so với cộng đồng các doanh nhân người Trung Quốc ở Ba Lan đã được nhận diện. Kết quả nghiên cứu cho thấy, để củng cố vị thế và nâng cao nhận thức kinh doanh của cộng đồng doanh nhân người Việt ở Ba Lan, đại sứ quán Việt Nam tại Ba Lan, các cơ quan xúc tiến thương mại Việt Nam ở nước ngoài và các hiệp hội người Việt Nam tại Ba Lan cần đóng vai trò tích cực để hỗ trợ các doanh nghiệp Việt Nam hiểu được tập tục kinh doanh bản địa, hòa nhập tốt hơn với môi trường kinh doanh và xã hội Ba Lan.

Từ khoá: Việt Nam, Ba Lan, kinh doanh, tinh thần khởi nghiệp 